\title{
PENERAPAN METODE PEMECAHAN MASALAH UNTUK MENINGKATKAN KREATIVITAS DAN BERPIKIR KRITIS SISWA DALAM PEMBELAJARAN IPA TENTANG GAYA GRAVITASI BUMI DI KELAS V SDN 9 LABUAN
}

\author{
Ofan \\ SD Negeri 9 Labuan \\ ofan@gmail.com
}

\begin{abstract}
ABSTRAK
Fakta yang terjai dalam proses pembelajaran selama ini yang bertanggung jawab di kelas V SDN 9 Labuan masih belum memberikan peluang kepada siswa untuk mengembangkan kreativitas dan kemampuan berpikir kritis siswa, terutama dalam pembelajaran Ilmu Pengetahuan Alam (IPA) tentang pokok bahasan "Gaya Gravitasi Bumi". Ditemukan hampir semua siswa tidak berani untuk mengutarakan pertanyaanmaupun pendapatnya selama proses pembelajaran. Dengan hasil pengalaman mengajar di SDN 9 Labuan seperti telah diungkapkan di atas, terutama motivasi dan prestasi belajar siswa terlalu rendah, sehingga apa yang diharapkan selama ini tidak dapat terlaksana dengan optimal. Upaya yang dilakukan penulis untuk mengatasi fenomena tersebut, yaitu memiih "Metode Pemecahan Masalah" dalam pembelajaran Ilmu Pengetahuan Alam (IPA) dengan pokok bahasan "Gaya Gravitasi Bumi",dimana kelas dikeolah menjadi-kelompok-kelompok kecil, dan masing-masing kelompok kecil tersebut diminta membahas topik yang diajarkan dengan bantuan LKS (Lembar Kerja Siswa) setelah mengamati hasidari percobaan/Demonstrasi yang diakukan oleh masing-masing kelompo kecil.
\end{abstract}

Kata Kunci : Metode Pemecahan Masalah, Kreativitas, Berpikir Kritis, Gaya Gravitasi Bumi

\begin{abstract}
Facts that have occurred in the learning process so far that are responsible in class V SDN 9 Labuan still have not provided an opportunity for students to develop creativity and critical thinking abilities of students, especially in learning Natural Sciences (IPA) about the subject of "Earth's Gravitational Force". It was found that almost all students did not dare to express their questions or opinions during the learning process. With the results of teaching experience at SDN Labuan 9 as stated above, especially the motivation and learning achievement of students is too low, so what is expected so far cannot be carried out optimally. Efforts made by the author to overcome this phenomenon, namely choosing "Problem Solving Method" in the study of Natural Sciences (IPA) with the subject "Earth Gravitational Force", where the class is processed into small groups, and each small group asked to discuss the topic taught with the help of LKS (Student Worksheet) after observing the results of an experiment / demonstration conducted by each small group.
\end{abstract}

Keywords: Problem Solving Method, Creativity, Critical Thinking, Earth's Gravitational Force

\section{PENDAHULUAN}

Ilmu Pengetahuan Alam (IPA) adalah ilmu yang mempelajari tentang mahluk hidup dan fenomena-fenomena yang terjadi di alam, maka dari itu siswa diharapkan dapat mengikuti pembelajaran 
IPA dengan baik dan efesien. Untuk itu guru diharapkan merenungi bagaimana merancang model, strategi, dan metode serta pendekatan pembelajaran yang tepat untuk keberhasilan pelaksanaan pendidikan.

Selama ini masih banyak yang menganggap bahwa siswa sebagai objek pendidikan, siswa datang ke sekolah dianggap botol kosong yang harus diisi oleh beberapa pengetahuan, yang kadang kurang memperdulikan kondisi dan kemampuan siswa. Guru menganggap dirinya paling super dan gudangnya ilmu, yang perlu menuangkan ilmunya begitu saja. Sedangkan siswa juga masih banyak yang menginginkan disuapi instan oleh sang guru sehingga ia datang ke sekolah dengan apa yang harus ia pelajari, seakan tanpa guru tidak ada pengetahuan yang diperolehnya, karena menganggap guru adalah satu-satunya sumber belajar. Kondisi yang demikian tidak sesuai pola pikir atau paradigma baru tentang pembelajaran.

Belajar dengan mengandalkan guru sebagai satu-satunya sumber telah membawa siswa bergantung pada guru. Interaksi terjadi hanya searah. Jawaban siswa dengan terbelenggu, merasa takut jika jawaban tidak sama, ide atau gagasan baru tidak berkembang, takut untuk bertanya, kawatir jika pertanyaan tidak mengena, belum lagi sulit untuk menyusun rangkaian kata-kata dalam menjawab dan bertanya dengan kalimat yang bagus, seringkali siswa tidak menghargai pendapat temannya, sehingga suasana kelas benar-benar tenang, tertib, sunyi, pasif dan inovasi dan kreativitas menjadi buntu. "Sutikno (2006:51) mengatakan bahwa realita proses pembelajaran yang terjadi di sekolah-sekolah selama ini sama sekali tidak memberikan peluang kepada siswa untuk mengembangkan kreativitas dan kemampuan berpikir kritis siswa. Siswa masih saja menjadi objek, mereka diposisikan sebagai orang yang tertindas, orang yang tidak tau apa-apa, orang yang harus dikasihani, oleh karena itu harus dijejali dan disuapi.

Dalam hal ini Sutikno menyampaikan bahwa: Model pendidikan dan pembelajaran yang memberi peluang yang lebih luas kepada peserta didik untuk terlibat langsung dalam mengkonstruksi pengetahuan dan pemahamannya dalam dalam proses "pemanusiaannya" mutlak ditumbuhkembangkan. (M Sobri Sutikno, 2006 : 51). Pada dasarnya dapat mengembangkan berbgai potensi yang dimilikinya secara optimal, yaitu mengembangkan potensi individu yang setinggi- tingginya dalam aspek fisik, intelektual, emosional, sosial dan spiritual, sesuai dengan tahap perkembangan serta karakteristik lingkungan fisik dan lingkungan sosial budaya dimana dia hidup.

Driarkara (1980) mengatakan bahwa pendidikan adalah memanusiakan manusia muda. Selanjutnya G. Thompson (1957) menyatakan bahwa pendidikan adalah pengaruh lingkungan atas individu untuk menghasilkan perubahan-perubahan yang tetap di alamkebiasaan-kebiasaan, pemikiran, sikap-sikap, dan tingka laku. Sejalan dengan pemikiran tersebut Crow and Crow (1960) mengemukakan harus diyakini bahwa funsi utama pendidikan adalah bimbingan terhadap individu dalam upaya memenuhi kebutuhan dan keinginan yang sesuai denga potensi yang dimilikinya sehingga dia memperoleh kepuasan dalam seluruh aspek kehidupan pribadi dan kehidupan sosialnya. Sunaryo Kartadinata (1996) mengemukakan pengertian pendidikan dalam rumusan yang sangat sederhana tetapi penuh makna, yaitu pendidikan adalah membawa manusia apa adanya kepada bagaimana seharusnya.

Menurut Piaget (William C, Crain, 1980:98) adalah benar bahwa belajar tidak harus berpusat pada guru/tenaga kependidikan, tetapi anak harus aktif. Oleh karena itu anak harus dibimbing agar aktif menemukan suatu yang dipelajarinya. Konsekuensinya materi dipelajari harus menarik minat belajar peserta didik dan menantang sehingga mereka asyik dan terlibat dalam proses pembelajaran.

Salah satu kemampuan yang harus dimiliki oleh guru, sebagai salah satu unsur pendidik, agar mampu melaksanakan tugas profesionalnya adalah memahami 
bagaimana mengorganisasikan proses pembelajaran yang mampu mengembangkan kemampuan dan membentuk watak peserta didik, serta memahami tentang bagaimana siswa belajar. Karena fungsi utama pembelajaran adalah memfasilitasi tumbuh dan berkembangnya belajar diri peserta didik.

Fotana (1981) mengartikan belajar adalah suatu proses perubahan yang relatif tetap dalam prilaku individu sebagai hasil dari pengalaman. Brower dan Halkgard (1981) yaitu bahwa belajar mengacu pada perubahan prilaku atau potensi individu sebagai hasil dari pengalaman dan perubahan tersebut tidak disebabkan oleh insting. Gagne (1985) mengemukakan 8 jenis belajar, diantaranya belajar pemecahan masalah (problem solving learning), yaitu belajar pemecahan masalah terjadi bila individu menggunakaan berbagai konsep atau prinsip untuk menjawab suatu pertanyaan. Didalam undang-undang No. 2 tahun 1989 telah dirumuskan bahwa tujuan pendidikan nasional adalah mencerdaskan kehidupan bangsa daan engembangkan manusia Indonesia seutuhnya, yaitu manusia yang beriman dan bertakwa terhadap Tuhan Yang Maha Esa dan berbudi pekerti yang luhur, memiliki pengetahuaan dan keterampilan, kesehatan jasmani dan rohani, kepribadian yang mantap dan mandiri serta rasa tanggung jawab kemasyarakatan dan kebangsaan.

Berdasarkan hasil dan pengalaman mengajar di SDN 9 Labuan khususnya di kelas V dalam pembelajaran IPA tentang "Gaya Gravitasi Bumi”, penulis merasakan bahwa kondisi selama pembelajaran terjadi hampir semua siswa masih belum berani untuk bertanya maupun mengemukakan pendapatnya, sehingga nampak di kelas sunyi dan pasif. Dengan demikian proses pembelajaran berjalan dengan mulus, namun motivasi dan prestasi siswa masih sangat rendah. Untuk menyikapi permasalahan tersebut, maka penulis perlu mengadakan Penelitian Tindakan Kelas (PTK) sehingga diharapkan hasil dari pembelajaran menjadi termotivasi dan kreatif, serta merangsang siswa untuk belajar.
Untuk mengatasi fenomena tersebut, upaya yang dilakukan penulis adalah menerapkan "Metode Pemecahan Masalah". Pemecahan masalah merupakan salah satu cara yang harus banyak digunakan dalam pembelajaran karena metode ini merupakan metode mengajar yang banyak mengembangkan kemampuan berpikir tingkat tinggi. Metode pemecahan masalah hakikatnya sama dengan kemampuan Inquiri dan Discovery. Aktivitas dalam proses belajar yang ditempuh siswa dapat dilakukan secara kelompok maupun individu, penentuannya bergantung pada target kemampuan dan tujuan pembelajaran yang akan dicapainya.

Pembelajaran berorientasi pada proses belajar pemecahan masalah mengacu pada proses mental individu dalam menghadapi suatu masalah untuk selanjutnya menemukan cara mengatasi masalah itu melalui proses berpikir yang sistematis dan cermat. Secara umum langkah-langkah pemecahan masalah adalah sebagai berikut :

1. Merasakan adanya masalah,

2. Merumuskan masalah secara khusus dalam bentuk pertanyaan atau pernyataan,

3. Memberikan jawaban sementara atau hipotesis atas masalah yang diajukan,

4. Mengumpulkan serta mengelolah data dan informasi dalam rangka menguji tepat tidaknya jawaban sementara yang diberikan,

5. Merumuskan kesimpulan mengenai pemecahan masalah tersebut dalam mencoba melihat kemungkinan penerapan dari kesimpulan itu.

Metode pemecahan masalaah sering juga digunakan dalam implementasi pembelajaran terpadu maupun kontekstual karena pembelajaran dikembangkan secara integritas antara kemampuan siswa dengan topik bahasan dan lingkungan. Jika dilihat dari filosofinya, metode ini cenderung menggunakan pendekatan "Kontruktivisme" artinya pengetahuan keterampilan dan sikap akan dikembangkan dan dibangun oleh siswa dibawa bimbingan guru. Jadi, dengan penerapan metode pemecahan masalah, penulis beranggapan dapat meningkatkan 
kreativitas dan berpikir kritis siswa dalam pembelajaran IPA di kelas V SDN 9 Labuan tentang Gaya Gravitasi Bumi

\section{METODE PENELITIAN}

Penelitian yang dilakukan merupakan penelitian tindakan kelas. Lokasi penelitian ini dilaksanakan di kelas V SDN 9 Labuan, Kecamatan Labuan, Kabupaten Donggala (Sulawesi Tengah), dengan jumlah siswa 13 orang, siswa laki-laki 8 orang dan siswa perempuan 5 orang. Tahap/siklus penelitian ini direncanakan dengan 2 siklus, masingmasing siklus terdiri dari perencanaan, pelaksanaan, observasi, dan refleksi.

\section{HASIL DAN PEMBAHASAN}

\section{A. Siklus I}

Siklus I dilaksanakan pada hari senin, 9 September 2019. Langkah-langkah pelaksanaan penelitian tindakan kelas yang dilakukan pada siklus I dalam upaya kemampuan guru mengefektifkan penggunaan metode pemecahan masalah. Sesuai hasil kesepakatan antara guru pelaksana PTK bersama teman sejawat sebagai supervisor maka pokok bahasan yang akan disajikan adalah "Gaya Gravitasi Bumi”. Adapun langkah-langkah pelaksanaan penelitian tindakan kelas siklus I sebagai berikut :

\section{Perencanaan}

Guru pelaksana PTK

berkolaborasi bersama guru/teman sejawat sebagai supervisor menentukan topik yang akan dibahas dalam perbaikan pembelajaran, yaitu "Gaya Gravitasi Bumi”. Adapun tujuan pembelajaran sebagai berikut : siswa dapat menjelaskan penyebab jatuhnaya setiap benda menuju ke bawah.

Guru pelaksana PTK bersama guru/teman sejawat menentukan waktu dan pengaturan kelompok kecil. Waktu yang digunakan 2 kali 2 pembelajaran (2 kali Pertemuan), siswa kelas V dibagi menjadi 3 kelompok.

\section{Tindakan}

Guru menjelaskan tujuan pembelajaran, kemudian memperkenalkan materi yang akan diajarkan. Guru membimbing masingmasing kelompok untuk melakukan percobaan dan mendiskusikannya dengan anggota kelompok masingmasing lalu mempersentasekan hasil diskusi mereka. Guru bersama siswa menyimpulkan materi pembelajaran.

\section{Observasi}

Kegiatan observasi dilakukan pada saat pembelajaran berlangsung, pengamatan dilakukan dengan seksama, baik yang dilakukan oleh guru maupun siswa. Pengamatan yang dilakukan oleh guru dengan menggunakan daftar ceklis yang merujuk pada 5 variabel ke-7 langkah dan kegiatan yang dilakukan oleh guru, yakni : 5 = sangat baik, 4 =baik, $3=$ sedang, 2 = cukup baik, 1 = kurang baik. Pengamatan yang dilakukan oleh siswa, selanjutnya dapat dikemukakan data kualitatif yang diobservasi baik oleh guru maupun siswa pada tabel 1 dan 2 .

Tabel 1. Kemampuan Guru Melakukan Perbaikan Pembelajaran pada Siklus I di Kelas V SDN 9 Labuan

\begin{tabular}{|c|c|c|c|c|c|c|}
\hline \multirow[b]{2}{*}{ No } & \multirow[b]{2}{*}{ Langkah dan Kegiatan } & \multicolumn{5}{|c|}{ Skala Penilaian } \\
\hline & & 1 & 2 & 3 & 4 & 5 \\
\hline 1. & Mengelolah ruangan dan fasilitas pembelajaran & & $\mathrm{V}$ & & & \\
\hline 2. & Melaksanakan pembelajaran & & & $\mathrm{V}$ & & \\
\hline 3. & Mengelolah interaksi kelas & & & $\mathrm{V}$ & & \\
\hline 4. & $\begin{array}{l}\text { Bersikap terbuka dan luwes serta membantu } \\
\text { pengembangan sikap positif siswa terhadap belajar }\end{array}$ & & $\mathrm{V}$ & & & \\
\hline 5. & $\begin{array}{l}\text { Mendemonstrasikan khusus dalam pembelajaran } \\
\text { mata pelajaran IPA }\end{array}$ & & & $\mathrm{V}$ & & \\
\hline 6. & Melaksanakan penilaian proses & & & $\mathrm{V}$ & & \\
\hline 7. & Kesan umum pembelajaran & & & $\mathrm{V}$ & & \\
\hline
\end{tabular}


Tabel 2. Siswa yang Bertanya dan Melakukan Kegiatan Lain Dalam Proses Pembelajaran dengan Menggunakan Metode Pemecahan Masalah pada Siklus I di Kelas V SDN 9 Labuan

\begin{tabular}{|c|c|c|c|c|}
\hline No & Jenis Kegiatan & $\begin{array}{l}\text { Siswa yang } \\
\text { Melakukan }\end{array}$ & Jumlah & $\begin{array}{l}\text { Persentase } \\
(\%)\end{array}$ \\
\hline 1. & $\begin{array}{ll}\text { Mengajukan pertanyaan pada } \\
\text { saat pembelajaran kerja } \\
\text { kelompok berlangsung }\end{array}$ & $\begin{array}{l}\text { Nur aira, arul, } \\
\text { riski }\end{array}$ & 3 orang & $23.07 \%$ \\
\hline 2. & $\begin{array}{l}\text { Bertanya kepada guru setelah } \\
\text { kesimpulan materi }\end{array}$ & & & \\
\hline 3. & $\begin{array}{l}\text { Keluar masuk kelas pada saat } \\
\text { pembelajaran kerja kelompok } \\
\text { berlangsung }\end{array}$ & $\begin{array}{l}\text { Devan, aril, nur } \\
\text { awalun, anggun, } \\
\text { rahman }\end{array}$ & 5 orang & $38.46 \%$ \\
\hline 4. & $\begin{array}{l}\text { Tidak serius dalam kegiatan } \\
\text { pembelajaran kerja kelompok }\end{array}$ & $\begin{array}{l}\text { Rahman, devan, } \\
\text { alif, nur abida, } \\
\text { aril, faozan }\end{array}$ & 6 orang & $46.15 \%$ \\
\hline
\end{tabular}

Berdasarkan hasil observasi yang ada pada tabel 1 tentang langkah-langkah pembelajaran yang dilakukan oleh guru di atas ada 7 langkah kegiatan yang dijadikan sebagai sasaran observasi peneliti, pada siklus I ini hanya langkah yang pertama yaitu aspek mengelolah ruangan dan fasilitas pembelajaran dan keempat yaitu bersikap terbuka dan luwes serta membantu mengembangkan sikap positif siswa terhadap belajar yang dikategorikan cukup baik, sedangkan yang dikategorikan sedang berada pada langkah kedua, ketiga, kelima dan ketujuh.

Berdasarkan hasil observasi pada tabel 2 siklus I tentang siswa yang bertanya dan kegiatan lain dilakukan oleh siswa pada saat kerja kelompok, dapat dipaparkan hasil yang dicapai sebagai berikut :

a. Mengajukan pertanyaan pada saat pembelajaran kerja kelompok berlangsung ada 3 orang siswa atau $23.07 \%$.

b. Bertanya kepada guru setelah kesimpulan materi, tidak ada seorangpun siswa yang bertanya.

c. Keluar masuk kelas saat pembelajaran kelompok berlangsung, ada 5 orang siswa atau $38.46 \%$.

d. Tidak serius dalam kegiatan pembelajaran kerja kelompok, ada 6 orang siswa atau $46.15 \%$.

\section{Refleksi}

Guru pelaksana PTK berkolaboasi bersama teman sejawat serta kepala sekolah melakukan diskusi untuk membahas hasil pelaksanaan tindakan yang dilakukan oleh guru dan hasil observasi yang didapatkan selama proses pembelajaran. Sesuai hasil observasi, bila dilihat dari segi kemampuan siswa bertanya ataupun mengutarakan pendapatnaya masih belum mencapai hasil yang diharapkan, yaitu kurangnya keberanian siswa untuk bertanya atau mengutarakan pendapatnya tentang hasil kerja kelompok.

\section{B. Siklus II}

Pada siklus II dilaksanakan pada hari senin, 16 September 2019. Dengan materi yang disajikan adalah materi bahasan yang sama pada siklusI, yakni "Gaya Gravitasi Bumi”. Dengan langkahlangkah sebagai berikut :

\section{Perencanaan}

Melihat hasil yang dicapai pada tindakan I, maka guru pelaksana PTK berkolaborasi bersama teman sejawat sebagai supervisor melakukan kembali diskusi untuk tindakan II dengan menetapkan hal-hal yang sama seperti perencanaan siklus I. Namun perlu merevisi untuk tindak lanjut pada siklus II ini dalam usaha kemampuan guru mengefektifkan penggunaan metode pemecahan masalah dalam pembelajaran IPA kelas V SDN 9 Labuan, secara umum adalah : 
a. Guru (pelaksana perbaikan pembelajaran) harus memberdayakan semua buku paket kelas $\mathrm{V}$ yang ada dengan membagikan kepada siswa untuk dipelajari sebelum melakukan kerja kelompok.

b. Guru (pelaksana perbaika pembelajaran) harus terlibat langsung dalam memotivasi anggota yang ada dengan membagikan kepada siswa untuk dipelajari sebelum melakukan kerja kelompok

\section{Tindakan}

Guru (pelaksana perbaikan pembelajaran) menjelaskan tujuan pembelajaran, menulis pokok materi yang akan dibahas pada papan tulis dan memberikan pengarahan tentang cara kerja kelompok. a. Guru (pelaksana perbaikan pembelajaran) mengarahkan siswa untuk melakukan percobaan/demonstrasi dan menjawab LKS (Lembar Kerja Siswa) yang telah dibagikan kepada masing-masing kelompok.

b. Guru (pelaksana perbaikan pembelajaran) meminta masingmasing kelompok untuk membacakan hasil dari pengamatan melalui percobaan/demonstrasi di depan kelas.

\section{Observasi}

Untuk mengetahui data hasil observasi tindakan II dapat dilihat pada tabel 3 dan tabel 4 berikut ini.

Tabel 3. Kemampuan Guru Melakukan Perbaikan Pembelajaran pada Siklus II di Kelas V SDN 9 Labuan

\begin{tabular}{|c|c|c|c|c|c|c|}
\hline \multirow[b]{2}{*}{ No } & \multirow[b]{2}{*}{ Langkah dan Kegiatan } & \multicolumn{5}{|c|}{ Skala Penilaian } \\
\hline & & 1 & 2 & 3 & 4 & 5 \\
\hline 1. & Mengelolah ruangan dan fasilitas pembelajaran & & & & & $\mathrm{V}$ \\
\hline 2. & Melaksanakan pembelajaran & & & & & V \\
\hline 3. & Mengelolah interaksi kelas & & & & & V \\
\hline 4. & $\begin{array}{l}\text { Bersikap terbuka dan luwes serta membantu } \\
\text { pengembangan sikap positif siswa terhadap belajar }\end{array}$ & & & & & V \\
\hline 5. & $\begin{array}{l}\text { Mendemonstrasikan khusus dalam pembelajaran } \\
\text { mata pelajaran IPA }\end{array}$ & & & & & V \\
\hline 6. & Melaksanakan penilaian proses & & & & & V \\
\hline 7. & Kesan umum pembelajaran & & & & & V \\
\hline
\end{tabular}

Tabel 4. Siswa yang Bertanya dan Melakukan Kegiatan Lain Dalam Proses Pembelajaran dengan Menggunakan Metode Pemecahan Masalah pada Siklus II di Kelas V SDN 9 Labuan

\begin{tabular}{|c|c|c|c|c|}
\hline No & Jenis Kegiatan & $\begin{array}{l}\text { Siswa yang } \\
\text { Melakukan }\end{array}$ & Jumlah & $\begin{array}{l}\text { Persentase } \\
(\%)\end{array}$ \\
\hline 1. & $\begin{array}{l}\text { Mengajukan pertanyaan pada } \\
\text { saat pembelajaran kerja } \\
\text { kelompok berlangsung }\end{array}$ & $\begin{array}{l}\text { Nur Aira, Rizki, Arul, } \\
\text { Devan, Anggun, } \\
\text { Faozan, Alif, Nur } \\
\text { Awalun, Failun }\end{array}$ & 9 orang & $69,23 \%$ \\
\hline 2. & $\begin{array}{l}\text { Bertanya kepada guru setelah } \\
\text { kesimpulan materi }\end{array}$ & $\begin{array}{l}\text { Nur Aira, Arul, Alif, } \\
\text { Riski, Nur } \\
\text { Abida }\end{array}$ & 5 orang & $38,46 \%$ \\
\hline 3. & $\begin{array}{l}\text { Keluar masuk kelas pada saat } \\
\text { pembelajaran kerja kelompok } \\
\text { berlangsung }\end{array}$ & & & \\
\hline 4. & $\begin{array}{l}\text { Tidak serius dalam kegiatan } \\
\text { pembelajaran kerja kelompok }\end{array}$ & & & \\
\hline
\end{tabular}


Berdasarkan hasil pengamatan yang digambarkan pada tabel 3 terhadap pelaksanaan tindakan II yang berpedoman pada langkah dankegiatan yang dilakukan oleh pelaksana PTK, maka dapat dijabarkan sebagai berikut : semua langkah dan kegiatan yang dilakukan oleh guru berada pada kriteria sangat baik. Semua langkah dan kegiatan yang dilakukan olehpelaksana PTK mengalami kemajuan dari kriteria sedang dan cukup baik menjadi sangat baik

Jika dibandingkan dengan siklus I dengan siklus II pada langkah kegiatan yangdilakukan oleh guru sudah mengalami perbaikan, sehingga secara menyeluruh pada siklus II yang dilakukan dapat dikategorikan berhasil. Dengan demikian guru telah secara nyata menunjukan kemampuan dan keterampilannya menggunakan metode pemecahan masalah untuk mengefektifkan pembelajaran IPA di kelas V SDN 9 Labuan dengan topik bahasan "Gaya Gravitasi Bumi"

Tabel 4 menggambarkan hasil observasi siswa yang bertanya ataupun mengutarakan pendapatnya dan melakukan kegiatan lain dalam proses pembelajaran dengan menggunakan metode pemecahan masalah pada siklus II. Jika dibandingkan data observasi pada siklus I terlihat adanya kemajuan di siklus II. Menurut pelaksana PTK dengan data observasi 4 di atas dapat disimpulkan bahwa pada siklus II ini sudah bisa dikategorikan dapat meningkatkan motivasi belajar dan dapat dikategorikan berhasil karena semua kelompok mengajukan atau mengutarakan pendapatnya.

Menurut pelaksana PTK pada siklus yang II ini guru benar-benar menunjukan kemampuan mengefektifkan penggunaan metode pemecahan masalah dalam pembelajaran IPA kelas V SDN 9 Labuan dengan topik bahasan "Gaya Gravitasi Bumi"

\section{Refleksi}

Pelaksanaan proses pembelajaran dengan menggunakan metode pemecahan masalah sangat perlu digunakan pada setiap pokok bahasan yang cocok untuk didiskusikan bukan hanya berlangsung sesaat tetapi dilaksanakan terus-menerus, agar kemampuan guru mengefektifkan penggunaan metode pemecahan masalah dalam setiap pembelajaran semakin sempurna sehingga siswa termotivasi untuk belajar dalam setiap pembelajaran.

Setelah pelaksana PTK memaparkan hasil observasi kegiatan guru dan siswa, kemudian perlu memaparkan hasil evaluasi pembelajaran pada tiap-tiap siklus sebagai data pendukung untuk lebih memperjelas peningkatan motivasi siswa, yang dipaparkan pada tabel 5 di bawah ini

Tabel 5. Daftar Nama-Nama Kelompok dan Hasil Evaluasi pada Siklus I dan II

\begin{tabular}{lcc}
\hline Kelompok/Nama Siswa & Nilai Siklus I & Nilai sikl us \\
\hline Kelompok I & & \\
1. Nur Aira & 70 & 100 \\
2. Alfatira & 60 & 85 \\
3. Nur Awalun & 65 & 85 \\
4. Nur Abidah & 65 & 80 \\
5. Anggun & 60 & 80 \\
Kelompok II & & \\
1. Riski & 60 & 90 \\
2. Devan & 55 & 80 \\
3. Aril & 65 & 75 \\
4. Faozan & 50 & 90 \\
Kelompok III & & \\
1. Alif & 70 & 95 \\
2. Arul & 55 & 80 \\
3. Rahman & 60 & 75 \\
4. Failun & 60 & 80
\end{tabular}




\begin{tabular}{lcc} 
Jumlah & 795 & 1095 \\
Nilai Rata-rata & 61.15 & 84.23 \\
Daya Serap & $61.15 \%$ & $84.23 \%$ \\
Ketuntasan Kriteria Minimal & Belum Tuntas & Tuntas \\
\hline
\end{tabular}

Berdasarkan hasil evaluasi di atas nampak perbedaan antara tindakan I dan tindakan II. Adapun hasil I memperoleh nilai rata-rata 61.15. Dari hasil tersebut di atas dapaat dikatakan belum memenuhi nilai ketuntasan nilai rata-rata, sebab standar keberhasilan untuk nilai rata-rata dalam mata pelajaran IPA adalah 70 . Selanjutnya pada siklus II sudah dapat dikategorikan berhasil

Selanjutnya untuk daya serap siswa pada siklus I diperoleh $61.15 \%$, jika ditinjau dari siswa belum dapat dikatakan berhasil karena standar untuk daya serap siswaharus $70 \mathrm{ke}$ atas. Pada siklus II mengalami peningkatan daya serap yaitu $84.23 \%$

Kemudian dikemukakan tingkat ketuntasan kriteria minimal, berdasarkan hasil pada siklus I belum memenuhi kriteria, karena ketuntasan kriteria minimal IPA adalah 70. Untuk siklus II nampak jelas sudah memenuhi ketuntasan kriteria minimal

\section{Pembahasan}

Setelah dipaparkan hasil observasi kegiatan yang dilakukan oleh guru maupun yang dilakukan oleh siswa dalam proses pembelajaran dengan menggunakan metode pemecahan masalah dan data evaluasi, peneliti juga memaparkan rumusan masalah penelitian tindakan kelas apakah benar dengan kemampuan guru mengefektifkan penggunaan metode pemecahan masalah dalam pembelajaran IPA dapat meningkatkan kreativitas dan berpikir kritis siswa di kelas $\mathrm{V}$ SDN 9 Labuan? Hal ini akan terlihat dari penjelasan berikut, berdasarkan data hasil observasi kegiatan siswa pada setiap tahap/siklus. Data ini berkaitan langsung dengan jenis kegiatan siswa didalam diskusi kerja kelompok, yaitu mengajukan pertanyaan ataupun mengutarakan pendapatnya

Pada siklus I, siswa bertanya 3 0rang siswa atau $23.07 \%$. Pada siklus II hampir semua siswa yang terlibat yaitu 9 orang siswa yang bertanya ataupun mengutarakan pendapatnya saat kegiatan pembelajaran berlangsung atau $69.23 \%$, sedangkan siswa yang bertanya ataupun mengutarakan pendapatnyasetelah kesimpulan materi yaitu 5 orang siswa atau $38.46 \%$.

$$
\text { Untuk memperjelas apakah }
$$
kemampuan guru dengan mengefektifkan penggunaan metode pemecahan masalah dalam pembelajaran dapat meningkatkan motivasi belajar siswa di kelas V SDN 9 Labuan? Maka perlu juga peneliti memaparkan hasil evaluasi pada setiap siklus dengan melihat nilai rata-rata siswa, daya serap, dan ketuntasan kriteria maksimal yakni pada siklus I nilai rata-rata 61.15. Pada siklus II mencapai 84.23. Selanjutnaya untuk daya serap siklus I hanya mencapai $61.15 \%$, pada siklus II mengalami peningkatan yakni 84.23\%. Kemudian pada tingkat ketuntasan kriteria minimal siklus I mencapai belum tuntas sedangkan pada siklus II sudah mengalami kategori melebihi tuntas. Berikut dapat dilihat dari pada tabel perbandingan hasil evaluasi untuk masing-masing siklus adalah sebagai berikut.

Tabel 6. Perbandingan Hasil Evaluasi pada Siklus I dan II

\begin{tabular}{clcc}
\hline No & Unsur yang dibandingkan & Siklus I & Siklus II \\
\hline 1. & Nilai Rata-rata & 61.15 & 84.23 \\
2. & Daya Serap & $61.15 \%$ & $84.23 \%$ \\
3. & Ketuntasan Kriteria Mininal & Belum Tuntas & Tuntas \\
\hline
\end{tabular}

Berdasarkan tabel di atas, maka dapat dikatakan bahwa kemampuan guru mengefektifkan penggunaan metode pemecahan masalah dalam pembelajaran IPA dapat meningkatkan motivasi belajar siswa di kelas V SDN 9 Labuan 
Setelah dilaksanakan pembelajaran oleh guru di kelas V SDN 9 Labuan dengan menggunakan metode pemecahan masalah untuk meningkatkan kreativitas dan berpikir kritis siswa, maka pelaksanaan tindakan untuk setiap siklus, ada beberapa hal yang merupakan faktor penghambat ditemukan di lapangan, hambatan tersebut antara lain :

1. Buku paket yang tersedia sangat terbatas sehingga dalam pelaksanaan tindakan kelas pada siklus I sangat sulit untuk memperluas pngetahuan siswa tentang materi yang diajarkan, sehingga sangat sulit untuk membuka cakrawala berpikir siswa untuk bertanya dan menjawab.

2. Penggunaan metode pemecahan masalah dalam proses pembelajaran masih jarang digunakan sehingga siswa masih merasa asing dengan belajar seperti ini.

3. Para siswa tidak mempunyai buku penunjang selain buku paket

\section{KESIMPULAN}

Berdasarkan keseluruhan penjelasan pada bab-bab terdahulu maka dapat dikemukakan beberapa kesimpulan yang berhubungan dengan pelaksanaan perbaikan pembelajaran melalui PTK ini, sebagai berikut:

1. Metode pemecahan masalah merupakan salah satu metode pembelajaran yang dapat dipilih dan kemudian diterapkan oleh guru guna meningkatkan motivasi belajar maupun meningkatkan prestasi belajar siswa. Peningkatan belajar siswa melalui metode pemecahan masalah dapat tercapai dengan baik asalkan pelaksanaan belajarnya dengan baik.

2. Data hasil kegiatan observasi kegiatan guru dan kegiatan siswa membuktikan bahwa dengan kemampuan guru mengefektifkan pnggunaan metode pemecahan masalah dalam pembelajaran IPA di kelas V SDN 9 Labuan motivasi siswa dapat ditingkatkan. Sebagaimana dinyatakan dalam pembahasan bahwa hanya pada siklus I siswa yang mengajukan pertanyaan ataupun yang mengutarakan pendapatnya persentasenya minim.

3. Menurut peneliti dengan data observasi pada tabel 4.3 dapat disimpulkan bahwa pada siklus II sudah dikategorikan dapat meningkatkan motivasi belajar dan kreativitas serta berpikir kritis siswa, dan berhasil karena hampir semua siswa telah mengajukan pertanyaan ataupun mengutarakan pendapatnya dan tidak seorangpun siswa keluar masuk ruangan saat pembelajaran berlangsung.

4. Peneliti menyatakan bahwa kemampuan guru mengefektifkan penggunaan metode pemecahan masalah dala pembelajaran IPA di kelas V SDN 9 Labuan siswa termotivasi untuk belajar. Hal ini dibuktikan dengan perolehan persentase pada siklus II, serta hasil evaluasi pada siklus II

\section{SARAN}

Dalam pelaksanaan proses perbaikan pembelajaran dengan menggunakan metode pemecahan masalah untuk meningkatkan kemampuan bertanya ataupun mengungkapkan pendapat siswa, maka saran-saran yang perludiperhatikan antara lain:

1. Peneliti menyarankan kepada guru untuk memberdayakan semua buku paket IPA kelas $\mathrm{V}$ yang ada dengan membagibagikan kepada siswa untuk dipelajari pada setiap pembelajaran. Dengan demikian para siswa memiliki kemampuan untuk bertanya ataupun mengutarakan pendapatnya tentang materi yang belum dimengerti

2. Kiranya guru mempunyai kemampuan dan keterampilan menggunakan berbagai metode dalam mengajar khususnya metode pemecahan masalah secara tepat dan efektif, agar pembelajaran lebih bermakna bagi siswa.

\section{DAFTAR PUSTAKA}

Djamarah, Sy. B. Zain, A. 2006. Strategi Belajar Mengajar. (ER). Jakarta : Rineka Cipta.

Tim FKIP. (2009). Pemantapan Kemampuan Profesional. (Cet. 4). Jakarta : Universitas Terbuka.

Mikarsa Lestari Hera, Taufik Agus, Prianto Lestari Puji (2007). 
Ofan

Pendidikan Anak di SD. (Cet. 9). Jakarta : Universitas Terbuka.

Asep Heri Herawan, dkk (2008). Pengembangan Kurikulum dan Pembelajaran. (Cet. 10). Jakarta : Universitas Terbuka.
Winata Putra, S. Udin, dkk (2007). Teori Belajar dan Pembelajaran. (Cet. 2). Jakarta : Universitas Terbuka.

W. Anitah, Sri, dkk (2002). Strategi Pembelajaran di SD. (Cet. 4).

Thaha. T (2002). Logika Mengoptimalkan Daya Pikir. Untad. Press. Jakar 